\title{
EVALUATION OF GENETIC DIVERGENCE AND HERITABILITY IN WINTER FIELD PEA GENOTYPES
}

Kosev V.

Institute of Forage Crops, Pleven, Bulgaria

An analysis was carried out during 2011-2013 on eight field pea genotypes. On the basis of the results obtained, the following conclusions may be drawn and used for further research on quantitative traits on forage pea and its application in breeding and development of new varieties. Analysis of variance showed significant differences betwen genotypes for all the investigated traits, except seed weight per plant. The genotypic coefficient of variation was higher than the genotypic coefficient of variation during the vegetation period. All the studied traits, except seeds number per pod and seed weight per plant, showed high heritability, indicating that these traits could be improved through selection procedure. Line №6 was classified as possessing a high general adaptability to the environment in terms of traits pod number per plant, seeds number per plant and vegetation period.

\section{Key words: breeding, genotype, Pisum sativum, productivity}

Introduction. Pea (Pisum sativum L.) is one of the oldest crop of the world; it was cultivated along with cereals like barley and wheat. Due to its very old history of domestication, versatile use as vegetables, pulses and feed, it is important food legume in the world [1,2].

The crop is grown in many countries and currently ranks fourth among the pulses in the world with cultivated area of 6.33 million hectares (ha) [3]. It is the major food legume with a valuable and cheap source of protein (23 to 25\%) having essential amino acids that has a high nutritional value for resource poor households [4].

Analysis of publications, pose the problem. Pea (Pisum sativum L.) is a major pulse crop, with 9.8 million tones of dry seeds produced worldwide in 2012. This production is distributed in many temperate regions of the world with 3.4 million in Europe, 3.3 million in North America and 2 millions in Asia. As a member of the large family of legume, pea presents both interesting biological features and attractive ecological conditions [5, 6, 7].

The crop has important ecological and economical advantages in many countries, as it plays a significant role in soil fertility restoration and also serves as a break crop suitable for rotation to minimize the negative impact of cereal-based mono-cropping [8].

To develop new varieties, a great diversity of baseline material and a vast of variability for desirable traits are needed. A good knowledge on genetic diversity or genetic similarity could be helpful in long term variety selection. Hence, genetic variability and diversity are of prime interest to plant breeders, as the plays a key role in framing and successful performing of breeding programs $[9,10]$.

The aim and tasks of the study. The research work in this study aims at studying the genetic variability and heritability on different traits of winter pea, which may help to select suitable genotypes for future breeding programs.

Materials and methods. The experimental study was conducted during 2011-2012 in the second experimental field of the Institute of Forage Crops, Pleven, Bulgaria. Eight winter pea (Pisum sativum ssp. arvense L.) genotypes were included in the trial, namely - №58 (Fenn x Pleven 4), №57

(c) Valentin Kosev. 2015.

ISSN 0582-5075. Селекція і насінництво. 2015. Випуск 108. 
(Fenn*x Pleven 4), №9 (Fenn x Usatii 90), №6 (Mir x Harkovsky etalon), №12A (Mir x Rezonator), №10 (Kerpo x Mir), №14 (Pleven 10 x Usatii 90) and standard variety Mir from our collection. In Table 1 some main characteristics of the parental forms - the varieties Fenn; Fenn*; Pleven 4; Usatii 90; Mir; Harkovsky etalon; Rezonator; Kerpo; Pleven 10. This breeding material was sown at three replicas in plots of $2 \mathrm{~m}^{2}$ with the row spacing of $20 \mathrm{~cm}$. The forage pea was grown by an approved technology of the Institute of Forage Crops, Pleven. Ten randomly selected plants from each genotype were marked and used to estimate yield components - plant height $(\mathrm{cm})$; seed number per plant and pod number per plant, 1000 seed weight (g); seed number per pod; seed weight per plant (g) and vegetation period (day). The statistical methods were used to process the experimental data: factor analysis by the method of principal components [11]; J. H. Ward hierarchical cluster analysis [12]; to group genotypes by similarity as a measure fo difference (the genetic distance), the Euclidean distance between them was used with previouslstandardization of the data. The broad sense heritability (Hbs) was calculated using the formula proposed by I. Mahmud and H. H. Kramer [13]. The genotypic coefficient of variation $(\mathrm{CVg})$ and phenotypic coefficient of variation $(\mathrm{GVe})$ were estimated by the formula suggested by G. W. Burton [14]. The analysis of adaptability were performed according to the methods proposed by M. Nascimento et al. [15].

Table 1

Distinctive features of the parental varieties

\begin{tabular}{|c|c|c|c|c|c|c|}
\hline Variety & Origin & Subspecies & Vine type & $\begin{array}{c}\text { Leaf } \\
\text { type }\end{array}$ & Stipule type & $\begin{array}{c}\text { Flower } \\
\text { color }\end{array}$ \\
\hline Fenn* & USA & arvense & long prostrate & acacia & rudimental & purple \\
\hline Fenn & USA & arvense & long prostrate & acacia & normal & purple \\
\hline Pleven 4 & Bulgaria & sativum & long semi erect & normal & normal & white \\
\hline Usatii 90 & Ukraine & sativum & long semi erect & afila & normal-wide & white \\
\hline Harkovsky etalon & Ukraine & sativum & short erect & afila & normal & white \\
\hline Mir & Bulgaria & arvense & long prostrate & normal & normal & purple \\
\hline Rezonator & Ukraine & sativum & long semi erect & normal & normal & white \\
\hline Kerpo & Bulgaria & sativum & short semi erect & normal & normal & white \\
\hline Pleven 10 & Bulgaria & arvense & long prostrate & normal & normal & purple \\
\hline
\end{tabular}

The computer software GENES 2009.7.0 for Windows XP [16] and Excel for Windows XP were used for all the analyses.

Results and discussion. Genetic diversity of germplasm determinates the limit of selection in crop improvement. Furthermore, knowledge of genetic associations among agronomic traits is regarded to considerable help maintain genetic improvements in breeding programs. Crop improvement with heritable traits and estimation of genetic parameters and their association are of prime importance in breeding (Esiyok et al., 2011).

The dispersion analysis indicated a significant variability for the all investigated traits, except seed weight per plant.

Estimation of genotypic $(G C V)$ and phenotypic coefficients of variation $(P C V)$. The comparison of traits in regard to the extent of genetic variation could be better judged by the estimation of the genotypic coefficient of variation $(\mathrm{CVg})$ in relation to their respective phenotypic coefficient of variation (CVe). Among the investigated, very small difference between $\mathrm{CVg}$ and CVe was observed for the traits such as plant height, pod number per plant and seed number per pod (Table 2). It indicates that the variations observed in the traits were mostly due to genetic factors. However, the environment played a little role in the expression of these trait. On the other hand, large difference between $\mathrm{CVg}$ and $\mathrm{CVe}$ was observed for the traits of 1000 seed weight and seed weight per plant. This indicated the role of environmental influence on these traits. 
Table 2

Genetic component of variation for quantitative traits in the investigated pea genotypes

\begin{tabular}{|c|c|c|c|c|c|c|c|c|}
\hline $\begin{array}{c}\text { Trait, pa- } \\
\text { rameter }\end{array}$ & $\begin{array}{c}\text { Plant } \\
\text { height }\end{array}$ & $\begin{array}{c}\text { Pods per } \\
\text { plant }\end{array}$ & $\begin{array}{c}\text { Seeds per } \\
\text { pod }\end{array}$ & $\begin{array}{c}\text { Seeds per } \\
\text { plant }\end{array}$ & $\begin{array}{c}1000 \\
\text { seed } \\
\text { weight }\end{array}$ & $\begin{array}{c}\text { Seed } \\
\text { weight } \\
\text { per plant }\end{array}$ & $\begin{array}{c}\text { Biomass } \\
\text { weight } \\
\text { perplant }\end{array}$ & $\begin{array}{c}\text { Vegeta- } \\
\text { tion peri- } \\
\text { od }\end{array}$ \\
\hline Min & 86.00 & 8.00 & 2.65 & 32.00 & 116.00 & 2.60 & 34.67 & 231.00 \\
\hline $\mathrm{Max}$ & 191.00 & 24.00 & 5.00 & 101.00 & 247.00 & 15.78 & 77.00 & 247.00 \\
\hline $\mathrm{CVg}(\%)$ & 9.17 & 12.76 & 2.46 & 7.76 & 8.55 & 8.99 & - & 1.94 \\
\hline $\mathrm{CVg} / \mathrm{CVe}$ & 0.75 & 0.57 & 0.23 & 0.37 & 0.50 & 0.24 & - & 4.46 \\
\hline$\sigma^{2} \mathrm{~g}$ & 185.34 & 3.66 & 0.01 & 22.40 & 186.25 & 0.44 & 0.80 & 21.86 \\
\hline$\sigma^{2} \mathrm{p}$ & 333.86 & 11.11 & 0.18 & 164.49 & 743.22 & 7.71 & 102.26 & 1.10 \\
\hline $\mathrm{H} 2(\%)$ & 62.48 & 49.70 & 14.08 & 29.00 & 42.92 & 14.72 & - & 98.35 \\
\hline
\end{tabular}

Note. CVg - genotypic coefficient of variation; CVe - phenotypic coefficient of variation; $\sigma^{2} \mathrm{~g}-$ genotypic variances; $\sigma^{2}$ p-phenotypic variances; $\mathrm{H}^{2}$ - broad sense heritability $(\%)$.

Estimation of heritability. Assessment of the heritable variation with heritability (broad sense) would give a reliable indication of the expected improvement through selection. High values of the broad sense heritability (Table 2) were recorded for the traits of vegetation period (98\%), plant height (62\%), pod number per plant (49\%) and 1000 seed weight (42\%). A heritability estimate provides guide for the selection procedure to be followed by the breeders for improvement of these traits in a given environment. Nawab et al., [4] also reported about a high heritability for 1000 seed weight. In earlier studies by Tezera (2000) and M. Fikreselassie [17, 18], high heritability estimates for phonological traits, seed number per plant and seed number per pod were reported. Thus, these findings are only partially in agreement with the results obtained in our investigation. The probable cause of the disparity could be due to the fact that the heritability of a given trait refers to a particular population under a particular condition or environment.

Estimation of phenotypic and genetic variances. The estimates of phenotypic variances of the quantitative traits were smaller than their corresponding genetic variances for parameter vegetation period. The genotypic variances ranged from 0.01 for the seed number per pod to 186.25 for 1000 seed weight. The genotypic variance was the highest for 1000 seed weight and plant height, indicating the greater magnitude of genetic variability for these traits. The phenotypic variance values ranged from 0.18 - to 743.22. The highest phenotypic variance was that of 1000 seed weight. The minimum phenotypic variance was observed for seed number per pod. Higher environmental variances were observed in plant height and seed number per plant. This indicates that both traits are highly influenced by the environment.

Principal component analysis. Principal component analysis was done to assess the patterns of variations by considering all the 8 variables simultaneously. There are two eigenvalues greater than 1 which determined the choice of the two main components. The first component accounted $53.14 \%$ and the second $-29.41 \%$ of the total variance. The main principal components (F1 and F2) accounted for more than $82 \%$ of the total variation in the field pea varieties (Table 3).

The first component was mainly related to the traits of plant height; pod number per plant, seed number per plant, 1000 seed weight, seed weight per plant and vegetation period. On formation of the second component, the characteristics seeds per pod and biomass weight per plant have been considered. The genotypes were very different among them also phenotypically (Figure 1). Line №14 characterized by positive values of the both components (F1 and F2). Mir, lines №9 and № 12A, which were arranged in the first quadrant, had positive values only for the component F2. Lines №10, №58 and №57 were situated on the fourth quadrant showing negative values of the both components. Genotype apart position in the quadrants showed that together they were phenotypically similar in a small number of traits. 
The Eigen values and vectors for 8 traits of pea genotypes

\begin{tabular}{|l|c|c|c|c|}
\hline \multicolumn{1}{|c|}{ TraitlPC } & F1 & F2 & F3 & F4 \\
\hline Plant height & $\mathbf{0 . 7 2 3}$ & 0.008 & 0.131 & 0.036 \\
\hline Pods per plant & 0.494 & 0.473 & 0.028 & 0.001 \\
\hline Seeds per pod & 0.013 & $\mathbf{0 . 6 4 1}$ & 0.303 & 0.038 \\
\hline Seeds per plant & $\mathbf{0 . 7 3 5}$ & 0.210 & 0.005 & 0.048 \\
\hline 1000 seed weight & $\mathbf{0 . 8 2 5}$ & 0.026 & 0.040 & 0.061 \\
\hline Seed weight per plant & $\mathbf{0 . 7 4 6}$ & 0.125 & 0.047 & 0.079 \\
\hline Biomass weight per/plant & 0.054 & $\mathbf{0 . 6 1 1}$ & 0.276 & 0.014 \\
\hline Vegetation period & $\mathbf{0 . 6 5 9}$ & 0.259 & 0.005 & 0.001 \\
\hline Eigenvalue & 4.249 & 2.353 & 0.834 & 0.279 \\
\hline Variability (\%) & 53.114 & 29.414 & 10.423 & 3.488 \\
\hline Cumulative \% & 53.114 & 82.529 & 92.952 & 96.440 \\
\hline
\end{tabular}

Note. Values in bold correspond for each variable to the factor for which the squared cosine is the largest; F1; F2; F3; F4 = principal component (PC) 1, 2, 3 and 4 respectively

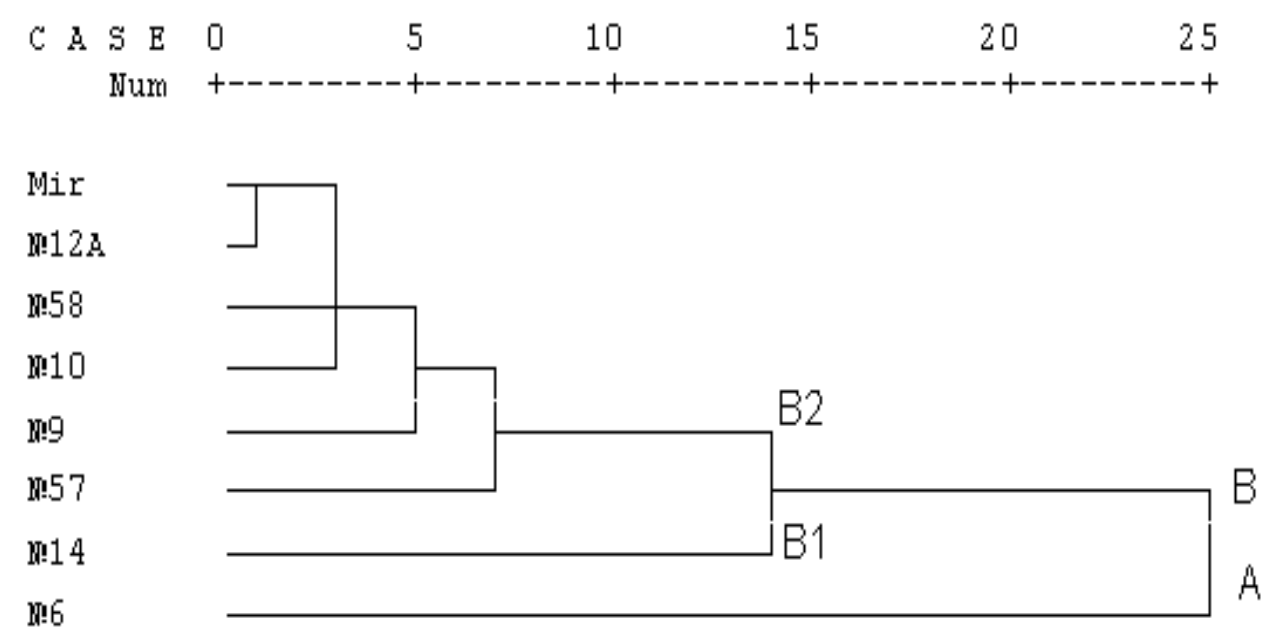

Figure 1. Dendrogram of winter pea genotypes

Cluster analysis. Hierarchical cluster analysis of the varieties was based on the basis of the values of the studied quantitative traits. The Euclidean distance was used as a measure for genetic distance. The results presented as a dendrogram (Figure 2) indicated the different grouping of the varieties by similarity and difference. Accessions were clustered into two main groups (A and B). The data showed that a significant genetic distance was observed between line №6 and the other genotypes. The plants from this hybrid were characterized by high values of the traits of pod number per plant, seed number per plant and 1000 seed weight and were separated into group " $A$ ". Genotype №14, which formed more seeds per pod and higher biomass weight than other lines and had the shortest vegetation period, belonged to subgroup "B1" based on the main group "B". The rest of genotypes formed the second branch in the same group. In this subgroup ("B2") there were also some diversities. Mir, lines №12A, №58 and №10 were genetically close by plant height, pod number per plant, seed number per plant and 1000 seed weight.

M. Fikreselassie et al. $[17,18]$ reported that upon calculating cluster mean, the superiority of a particular accession with respect to a given character could get diluted by other accessions that are 
grouped in the same cluster but are inferior or intermediate for the trait in question. Hence, apart from selecting genotypes from the clusters, which have higher inter-cluster distance, for hybridization, one shuld also concider selecting parents on the basis of the extent of divergence with respect to a trait of interest. Singly they are introduced lines №9 and № 57. The hierarchical cluster analysis can be used in breeding to plan the initial parent combinations [19].

Scree plot

Obsentione (axes F1 and F2:82.53 \%)
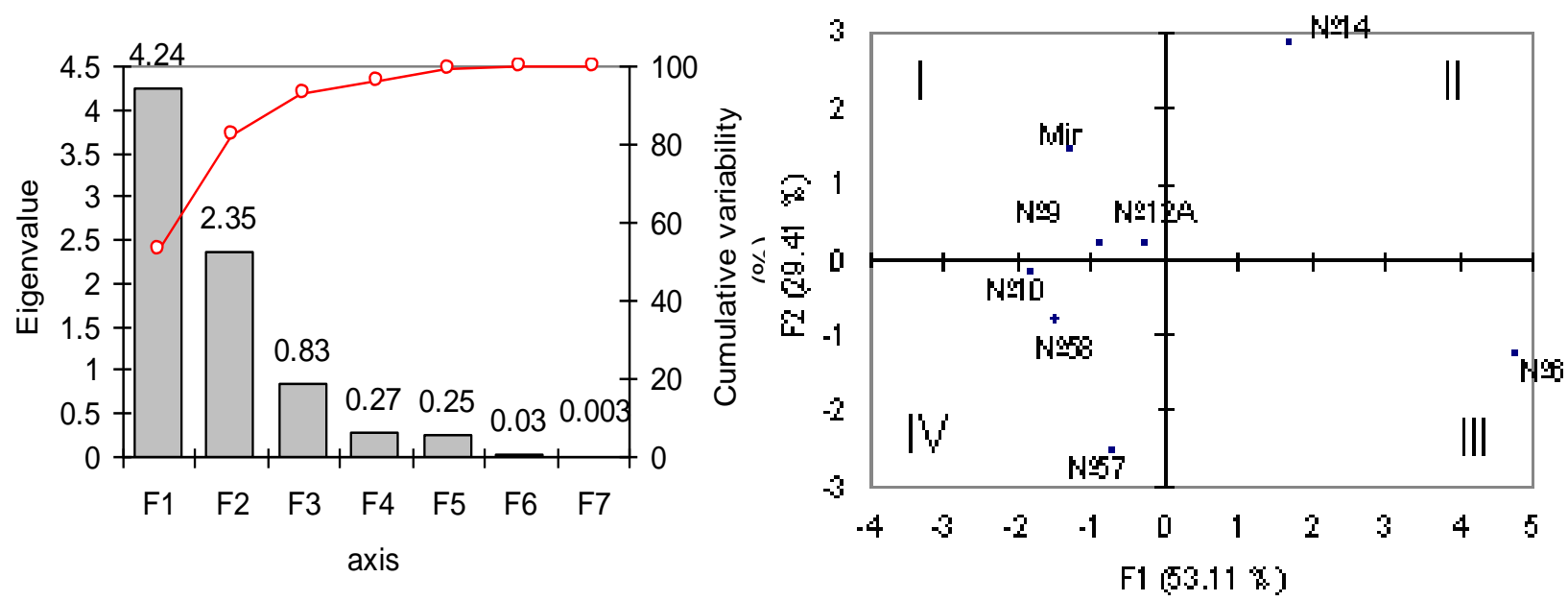

Figure 2. Principal component analysis of quantitative traits of winter pea genotypes

Analysis of adaptability. By the centroid method (Table 4), it was found that line № 10 belonged to class IV for the traits of pod number per plant and seed number per plant; line № 57 - for seed weight per plant and biomass weight per plant, i.e. behaving as poorly adapted genotypes for these traits. Lines № 58 line had a medium overall adaptability for almost all traits, except seed number per pod and biomass weight per plant, being grouped in Class V. Line №6 was referred to Class I for pod number per plant, seed number per plant and vegetation period represents a high general adaptability.

Table 4

Estimation of parameters of adaptability of eight pea hybrid lines and cultivar Mir for yield's components, based on the methodologies of centroid (Nascimento et al., 2009)

\begin{tabular}{|c|c|c|c|c|c|c|c|c|}
\hline $\begin{array}{c}\text { Genoty } \\
\text { pes }\end{array}$ & Plant height & $\begin{array}{c}\text { Ran } \\
k\end{array}$ & $\begin{array}{l}\text { Pods per } \\
\text { plant }\end{array}$ & $\begin{array}{c}\text { Ran } \\
k\end{array}$ & Seeds per pod & $\begin{array}{c}\text { Ran } \\
k\end{array}$ & $\begin{array}{c}\text { Seeds per } \\
\text { plant }\end{array}$ & $\begin{array}{c}\text { Ran } \\
k\end{array}$ \\
\hline Mir & $157.67^{b}$ & VI & $12.67^{\mathrm{a}}$ & IV & $4.14^{\mathrm{ab}}$ & VII & $53.67^{\mathrm{a}}$ & IV \\
\hline №58 & $152.00^{b}$ & $\mathrm{~V}$ & $14.00^{\mathrm{a}}$ & $\mathrm{V}$ & $4.18^{b}$ & VII & $58.50^{\mathrm{a}}$ & $\mathrm{V}$ \\
\hline №57 & $162.50^{b}$ & VII & $18.00^{\mathrm{ab}}$ & V & $3.43^{\mathrm{a}}$ & IV & $62.50^{\mathrm{ab}}$ & V \\
\hline №9 & $155.33^{b}$ & VII & $14.33^{\mathrm{a}}$ & $\mathrm{V}$ & $4.15^{\mathrm{ab}}$ & VI & $60.33^{\mathrm{ab}}$ & $\mathrm{V}$ \\
\hline №6 & $109.00^{\mathrm{a}}$ & IV & $20.33^{b}$ & I & $3.87^{\mathrm{ab}}$ & V & $81.00^{b}$ & I \\
\hline №12A & $161.00^{b}$ & VI & $14.33^{\mathrm{a}}$ & $\mathrm{V}$ & $4.07^{\mathrm{ab}}$ & $\mathrm{V}$ & $61.67^{\mathrm{ab}}$ & $\mathrm{V}$ \\
\hline №10 & $146.00^{b}$ & V & $13.00^{\mathrm{a}}$ & IV & $4.04^{\mathrm{ab}}$ & V & $53.00^{\mathrm{a}}$ & IV \\
\hline №14 & $144.67^{b}$ & $\mathrm{~V}$ & $13.33^{\mathrm{a}}$ & IV & $4.25^{b}$ & VII & $57.33^{\mathrm{a}}$ & $\mathrm{V}$ \\
\hline Mir & $142.47^{\mathrm{a}}$ & $\mathrm{V}$ & $7.40^{\mathrm{a}}$ & $\mathrm{V}$ & $56.78^{\mathrm{ab}}$ & VI & $243^{\mathrm{d}}$ & $\mathrm{V}$ \\
\hline №58 & $158.50^{\mathrm{ab}}$ & $\mathrm{V}$ & $5.31^{\mathrm{a}}$ & $\mathrm{V}$ & $41.47^{\mathrm{a}}$ & VI & $246^{\mathrm{e}}$ & $\mathrm{V}$ \\
\hline №57 & $147.50^{\mathrm{a}}$ & $\mathrm{V}$ & $6.32^{\mathrm{a}}$ & IV & $47.71^{\mathrm{ab}}$ & IV & $246^{\mathrm{e}}$ & I \\
\hline №9 & $142.33^{\mathrm{a}}$ & III & $7.83^{\mathrm{a}}$ & IV & $50.31^{\mathrm{ab}}$ & $\mathrm{V}$ & $245^{\mathrm{e}}$ & I \\
\hline
\end{tabular}




\begin{tabular}{|c|c|c|c|c|c|c|c|c|}
\hline $\begin{array}{c}\text { Genoty } \\
\text { pes }\end{array}$ & $\begin{array}{c}1000 \text { seed } \\
\text { weight }\end{array}$ & $\begin{array}{c}\text { Ran } \\
\mathrm{k}\end{array}$ & $\begin{array}{c}\text { Seed weight per } \\
\text { plant }\end{array}$ & $\begin{array}{c}\text { Ran } \\
\mathrm{k}\end{array}$ & $\begin{array}{c}\text { Biomass weight } \\
\text { per/plant }\end{array}$ & $\begin{array}{c}\text { Ran } \\
\mathrm{k}\end{array}$ & $\begin{array}{c}\text { Vegetation } \\
\text { period }\end{array}$ & $\begin{array}{c}\text { Ran } \\
\mathrm{k}\end{array}$ \\
\hline №6 & $196.13^{\mathrm{b}}$ & $\mathrm{V}$ & $10.06^{\mathrm{a}}$ & $\mathrm{V}$ & $48.83^{\mathrm{ab}}$ & $\mathrm{II}$ & $236^{\mathrm{b}}$ & $\mathrm{I}$ \\
\hline №12A & $154.50^{\mathrm{ab}}$ & VII & $7.78^{\mathrm{a}}$ & VI & $47.55^{\text {ab }}$ & V & $239^{\mathrm{c}}$ & IV \\
\hline №10 & $147.50^{\mathrm{a}}$ & $\mathrm{V}$ & $5.28^{\mathrm{a}}$ & $\mathrm{V}$ & $47.91^{\mathrm{ab}}$ & $\mathrm{V}$ & $246^{\mathrm{e}}$ & V \\
\hline №14 & $187.73^{\text {ab }}$ & V & $9.31^{\mathrm{a}}$ & IV & $59.87^{\text {ab }}$ & V & $234^{\mathrm{a}}$ & $\mathrm{I}$ \\
\hline
\end{tabular}

Note. Rank I: high general adaptability; Rank II: specific adaptability to favorable environments; Rank III: Specific adaptability to adverse environments; RankIV: Partially adapted; RankV: Adaptability overall average; RankVI: specific adaptability to favorable environments; RankVII: Adaptability specific to unfavorable environments. a, b, c, - statistically proven differences in $\mathrm{P}=0.05$

Conclusions. On the basis of the results obtained, the following conclusions may be drawn and used for further research on the quantitative traits on forage pea and its application in breeding and the development of new varieties. Analysis of variance showed significant differences among genotypes for the all investigated traits, except seed weight per plant. The analysis of coefficient of variation showed that the genotypic coefficient of variation was higher than the phenotypic coefficient of variation for the vegetation period. For all the traits studied, except the seed number per pod and seed weight per plant, high heritability was observed, indicating that these traits could be improved through selection. Line №6 was classified as hawing a high general adaptability to the environment for pod number per plant, seed number per plant and vegetation period.

\section{References}

1. McPhee, K. Dry pea production and breeding, a mini-review [Text] / K. McPhee // Food Agric. Environ. - 2003. - No 1. - P. 64-69.

2. Choudhury, R. P. Identification and detection of genetic relatedness among important varieties of pea (Pisum sativum L.) grown in India [Text] / R. P. Choudhury, H. Tanveer, G. P. Dixit // Genetica. - 2006. - No 130. - P. 183-191.

3. FAOSTAT [Internet]. 2012. Available from: http://faostat.fao.org/.

4. Nawab, N. N. Genetic variability, correlation and path analysis studies in garden pea (Pisum sativum L.) [Text] / N. N. Nawab, G. M. Subhani, K. Mahmood, Q. Shakil, A. Saeed // J. Agric. Res. - 2008. - No 46, Issue 4. - P. 333-340.

5. Smýkal, P. Pea (Pisum sativum L.,) in the genomic era [Text] / P. Smýkal, G. Aubert, J. Burstin, C. J. Coyne, N. T. H. Ellis, A. J. Flavell et al. // Agronomy. - 2012. - No 2, Issue 2. - P. 74-115. doi:10.3390/agronomy2020074.

6. FAOSTAT. Food and agriculture organization corporate statistical database [Internet]. 2014. Available from: http://faostat.fao.org.

7. Burstin J. Genetic diversity and trait genomic prediction in a pea diversity panel [Text] / J. Burstin, P. Salloignon, M. Chabert-Martinello, J. B. Magnin-Robert et al. // BMC Genomics. 2015. - No 16. - 105 p. doi:10.1186/s12864-015-1266-1.

8. Angaw, T. S. Fertilizer response trials on highlands food legumes. In: Cool -season food legumes of Ethiopia [Text] / T. S. Angaw, W. Asnakew; In: Asfaw T., editor. - ICARDA, Alepo, Syria. 1994. - P. 279-292.

9. Kumar, H. Genetic enhancement of variability through induced mutagenesis in two genotypes of Brassica napus L. [Text] / H. Kumar, A. Srivastava, M. K. Vishwakarma, J. P. Lal // Madras Agric. J. - 2012. - No 99, Issue 4-6. - P. 228-231.

10. Saxesena, R. R. Diversity analysis and identification of promising lines for hybridization in field pea (Pisum sativum L.) [Text] / R. R. Saxesena, G. M. Lal, P. S. Yadav, M. K. Vishwakarma // The Bioscan. - 2013. - No 8, Issue 4. - P. 1437-1440. 
11. Vandev, D. L. Notes on Applied Statistics 1 [Text] / D. L. Vandev. - Cy “St. K1. Ochridsky", Sf. (In Bg). - 2003.

12. Ward, J. H. Hierarchical grouping to optimize an objective function [Text] / J. H. Ward // Journal of the American Statistical Association. - 1963. - No 58. - P. 236-244.

13. Mahmud, I. Segregation for yield high and maturity fallowing a soybean cross [Text] / I. Mahmud, H. H. Kramer // Agricultural Journal. - 1951. - No 1. - P. 505-509.

14. Burton, G. W. Quantitative inheritance in grasses [Text] / G. W. Burton // Proc. 6th Int. Grassld. Cong. - 1952. - No 1. - P. 277-283.

15. Nascimento, M. Change in centroid method for assessing genotypic adaptability [Text] / M. Nascimento, C. D. Cruz, A. C. M. Campana, R. S. Tomaz et al. // Agricultural Research Brazil. 2009. - No 44, Issue 3. - P. 263-269.

16. Cruz, C. D. Programa Genes: Biometria. version 7.0 [Text] / C. D. Cruz. - University of Federal Viçosa, Viçosa, Brazil. - 2009.

17. Fikreselassie, M. Variability, heritability and association of some morpho-agronomic traits in field pea (Pisum sativum L.) genotypes [Text] / M. Fikreselassie // Pakistan Journal of Biological Sciences. - 2012. - No 15. - P. 358-366.

18. Fikreselassie, M. Correlation and path analysis in ethiopian fenugreek (Trigonella foenumgraecum L.) landraces [Text] / M. Fikreselassie, H. Zeleke, N. Alemayehu // Crown Res. Edu. 2012. - No 210. - P. 132-142.

19. Dragavtsev, V. A. Redetermination of genetically formulae of quantitative characters in different environmental conditions [Text] / V. A. Dragavtsev, A. F. Averyanova // Genetica Rus. - 1983. No 11. - P. 1811-1817.

\section{References CBE/CSE}

1. McPhee, K. Dry pea production and breeding, a mini-review. Food Agric. Environ. 2003; 1: 6469.

2. Choudhury RP, Tanveer H, Dixit GP. Identification and detection of genetic relatedness among important varieties of pea (Pisum sativum L.) grown in India. Genetica. 2006; 130: 183-191.

3. FAOSTAT. 2012. Available from: http://faostat.fao.org/.

4. Nawab NN, Subhani GM, Mahmood K, Shakil Q, Saeed A. Genetic variability, correlation and path analysis studies in garden pea (Pisum sativum L.). J. Agric. Res. 2008; 46(4):333-340.

5. Smýkal P, Aubert G, Burstin J, Coyne CJ, Ellis NTH, Flavell AJ et al. Pea (Pisum sativum L.,) in the genomic era. Agronomy. 2012; 2(2):74-115. doi:10.3390/agronomy2020074.

6. FAOSTAT. Food and agriculture organization corporate statistical database. 2014. Available from: http://faostat.fao.org.

7. Burstin J, Salloignon P, Chabert-Martinello M, Magnin-Robert JB, Siol M, Jacquin F, Chauveau A, Pont C, Aubert G, Delaitre C, Truntzer C, Duc G. Genetic diversity and trait genomic prediction in a pea diversity panel. BMC Genomics. 2015; 16:105. doi:10.1186/s12864-015-1266-1.

8. Angaw TS, Asnakew W. Fertilizer response trials on highlands food legumes. In: Cool -season food legumes of Ethiopia. In: Asfaw T, editor. ICARDA, Alepo, Syria. 1994; 279-292.

9. Kumar H, Srivastava A, Vishwakarma MK, Lal JP. Genetic enhancement of variability through induced mutagenesis in two genotypes of Brassica napus L. Madras Agric. J. 2012; 99(4-6): 228231.

10. Saxesena RR, Lal GM, Yadav PS, Vishwakarma MK. Diversity analysis and identification of promising lines for hybridization in field pea (Pisum sativum L.). The Bioscan. 2013; 8(4): 1437 1440.

11. Vandev, DL. Notes on Applied Statistics 1, Cy "St. K1. Ochridsky", Sf. (In Bg). 2003.

12. Ward, JH. Hierarchical grouping to optimize an objective function. Journal of the American Statistical Association. 1963; 58: 236-244. 
13. Mahmud I, Kramer HH. Segregation for yield high and maturity fallowing a soybean cross. Agricultural Journal. 1951; 1: 505-509.

14. Burton GW. Quantitative inheritance in grasses. Proc. 6th Int. Grassld. Cong. 1952; 1: 277-283.

15. Nascimento M, Cruz CD, Campana ACM, Tomaz RS, Salgado CC, Ferreira R. Change in centroid method for assessing genotypic adaptability. Agricultural Research Brazil. 2009; 44(3): 263269.

16. Cruz CD. Programa Genes: Biometria. version 7.0. University of Federal Viçosa, Viçosa, Brazil. 2009.

17. Fikreselassie M. Variability, heritability and association of some morpho-agronomic traits in field pea (Pisum sativum L.) genotypes. Pakistan Journal of Biological Sciences. 2012; 15: 358366.

18. Fikreselassie M, Zeleke H, Alemayehu N. Correlation and path analysis in ethiopian fenugreek (Trigonella foenum-graecum L.) landraces. Crown Res. Edu. 2012; 210: 132-142.

19. Dragavtsev VA, Averyanova AF. Redetermination of genetically formulae of quantitative characters in different environmental conditions. Genetica Rus. 1983; 11: 1811-1817.

\section{ОЦІНКИ ГЕНЕТИЧНӦ̈ МІНЛИВОСТІ ТА СПАДКОВОСТІ У ГЕНОТИПІВ ГОРОХУ В ПОСІВАХ ПІД ЗИМУ}

Косев В.

Інститут кормових культур, Плевен, Болгарія

Мета і задачі дослідження. Науково-дослідна робота спрямована на вивчення генетичної мінливості і спадковості за різними ознаками у гороху в підзимньому посіві, що може сприяти у доборі генотипів для майбутніх селекційних програм.

Матеріали і методи. Дослідження проведено в 2011-2012 рр. в Інституті кормових культур, Плевен, Болгарія. Вихідним матеріалом були вісім генотипів - № 58 (Fenn x Pleven 4), № 57 (Fenn*x Pleven 4), № 9 (Fenn x Вусатий 90), № 6 (Mir x Харківський еталонний), № 12A (Mir x Резонатор), № 10 (Kerpo x Mir), № 14 (Pleven 10 х Вусатий 90), за стандарт був сорт

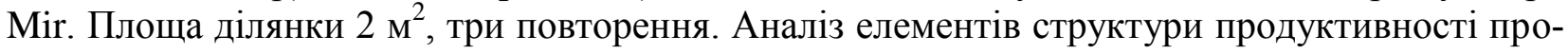
водили на 10 рослинах, також визначали тривалість вегетаційного періоду.

Статистичну обробку проводили за допомогою дисперсійного аналізу (D. L. Vandev), iєpapxiчного кластерного (J. H. Ward). Спадковість у широкому сенсі визначали за формулою I. Mahmud, H. H. Kramer, коефіцієнти генотипової та фенотипової варіації - за формулою М. Fikreselassie.

Обговорення результатів. Дисперсійний аналіз підтвердив наявність істотних відмінностей за всіма показниками, за виключенням ваги насіння з рослини. Так, незначну різницю відмічено між коефіцієнтами генотипової і фенотипової варіації у ознак висота рослини, кількість бобів на рослині і кількість насінин у бобі. Це свідчить про те, що мінливість цих ознак пов'язана з генетичними чинниками. Для маси 1000 насінин мінливість обумовлена екологічними чинниками.

Високі коефіцієнти успадковуваності в широкому сенсі відмічено у тривалості вегетаційного періоду (98 \%), висоти рослини (62\%), кількості бобів на рослині (42\%) і маси 1000 насінин (42\%). Такі дані частково не узгоджуються з даними інших дослідників, що може свідчити про те, що коефіцієнти успадковуваності є коректними лише для даної популяції в даних умовах.

Методом центроїда визначено, що лінія № 10 має низьку адаптованість за кількістю бобів та насінин на рослині, лінія № 57 - за вагою насіння та біомаси рослини. Високою адаптованістю характеризується лінія № 6 за кількість бобів і насінин на рослині та тривалістю вегетації. 
Висновки. Дисперсійний аналіз показав істотні відмінності між генотипами за всіма ознаками, крім ваги насіння з рослини. Результати аналізу за коефіцієнтом варіації показали, що генотипова мінливість визначає тривалість вегетації. Для всіх вивчених ознак, за винятком кількості насіння в бобі та вагою насіння з рослини, було виявлено високі коефіцієнти генотипової мінливості. Це означає, що ці ознаки можуть бути покращені шляхом добору.

Лінія № 6 (Mir x Харківський еталонний) відзначається високою адаптованістю за кількість бобів і насінин на рослині та тривалістю вегетації.

Ключові слова: селекція, генотип, Pisum sativum, продуктивність

\section{ОЦЕНКА ГЕНЕТИЧЕСКОЙ ИЗМЕНЧИВОСТИ И НАСЛЕДУЕМОСТИ У ГЕНОТИПОВ ГОРОХА В ПОДЗИМНЕМ ПОСЕВЕ}

Косев В.

Институт кормовых культур, Плевен, Болгария

Цель и задачи исследования. Научно-исследовательская работа направлена на изучение генетической изменчивости и наследуемости по разным признакам у гороха в подзимнем посеве, что может способствовать добору генотипов для будущих селекционных программ.

Материалы и методы. Исследования проведены в 2011-2012 гг. в Институте кормовых культур, Плевен, Болгария. Исходным материалом были восемь генотипов - № 58 (Fenn x Pleven 4), № 57 (Fenn*x Pleven 4), № 9 (Fenn x Усатый 90), № 6 (Mir x Харьковский эталонный), № 12A (Mir х Резонатор), № 10 (Kerpo х Mir), № 14 (Pleven 10 х Усатый 90), стандар-

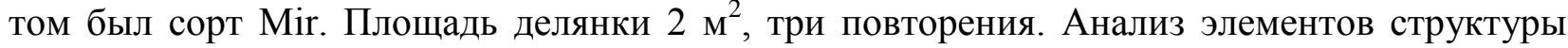
продуктивности проводили на 10 растениях, также определяли продолжительность вегетационного периода.

Статистическую обработку проводили при помощи дисперсионного анализа (D. L. Vandev), иерархического кластерного (J. H. Ward). Наследуемость в широком смысле определяли по формуле I. Mahmud, H. H. Kramer, коэффициенты генотипической и фенотипической вариации - по формуле М. Fikreselassie.

Обсуждение результатов. Дисперсионный анализ подтвердил наличие существенных различий по всем показателям, за исключением веса семян с растения. Так, незначительная разница отмечена между коэффициентами генотипической и фенотипической вариации по признакам высота растения, количество бобов на растении и количество семян в бобе. Это свидетельствует о том, что изменчивость этих признаков связана с генетическими факторами. Для массы 1000 семян изменчивость обусловлена экологическими факторами.

Высокие коэффициенты наследуемости в широком смысле отмечены по продолжительности вегетационного периода (98\%), высоте растений (62\%), количеству бобов на растении (42 $\%$ и массе 1000 семян (42 \%). Такие данные частично не согласуются с данными других исследователей, что может свидетельствовать о том, что коэффициенты наследуемости являются корректными только для данной популяции в данных условиях.

Методом центроида определено, что у линии № 10 низкая адаптированность по количеству бобов и семян на растении, у линии № 57 - по весу семян и биомассы растений. Высокой адаптированностью характеризуется линия № 6 по количеству бобов и семян на растении и продолжительности вегетации.

Выводы. Дисперсионный анализ показал существенные различия между генотипами по всем признакам, кроме веса семян с растения. Результаты анализа по коэффициенту вариации показали, что генотипическая изменчивость определяет продолжительность вегетации. Для всех изученных признаков, за исключением количества семян в бобе и веса семян с растения, были обнаружены высокие коэффициенты генотипической изменчивости. Это значит, что эти признаки могут быть улучшены путем отбора. 
Линия № 6 (Mir x Харьковский эталонный) выделяется высокой адаптированностью по количеству бобов и семян на растении и продолжительности вегетации.

Ключевые слова: селекиия, генотип, Pisum sativum, продуктивность

\section{EVALUATION OF GENETIC DIVERGENCE AND HERITABILITY IN WINTER FIELD PEA GENOTYPES}

Kosev V.

Institute of Forage Crops, Pleven, Bulgaria

The aim and tasks of the study. The research was aimed at studying genetic variability and heritability for various traits of winter pea, which may contribute to selection of genotypes for further breeding programs.

Materials and methods. The investigations were carried out at the Institute of Forage Crops (Pleven, Bulgaria) in 2011-2012. The starting materials was eight genotypes - No 58 (Fenn $\mathrm{x}$ Pleven 4), No 57 (Fenn x Pleven 4), No 9 (Fenn x Usatyy 90), No 6 (Mir x Kharkovskiy Etalonnyy), No 12A (Mir x Rezonator), No 10 (Kerpo x Mir), No 14 (Pleven 10 x Usatyy 90). Variety 'Mir' served as the standard. The plot area was $2 \mathrm{~m}^{2}$ in three replicas. Structural elements of productivity were analyzed for 10 plants. The growing season length was also determined.

Statistical processing was performed using analysis of variance (DL Vandev) and hierarchical cluster analysis (JH Ward). The heritability in broad sense was determined by the I. Mahmud and $\mathrm{HH}$ Kramer's formula; the coefficients of genotypic and phenotypic variation - by the M. Fikreselassie's formula.

Results and discussion. Analysis of variance confirmed significant differences for all parameters, except for 'seed weight per plant'. Small differences were observed between the coefficients of genotypic and phenotypic variation for the traits of 'plant height', 'pod number per plant' and 'seed number per pod'. This suggests that the variability of these traits is linked to genetic factors. For '1000-seed weight', variability is due to environmental factors.

High coefficients of heritability in broad sense were obtained for the growing season length (98\%), plant height (62\%), pod number per plant (42\%), and 1000-seed weight (42\%). These data do not partially tally with other investigators' ones, which may indicate that the heritability coefficients are valid only for a given population under given conditions.

The centroid method determined that line No 10 was low adaptable by the pod and seeds numbers per plant; line No 57 - by seed weight and plant biomass. Line No 6 was noticeable for high adaptability by the pod seed numbers per plant and growing season length.

Conclusions. Analysis of variance showed significant differences between genotypes for all traits, except for 'seed weight per plant'. The results of analyzing the coefficient of variation showed that genotypic variability determines the growing season length. All the test traits, except for 'seed number per pod' and 'seed weight per plant' were found to have high coefficients of genotypic variability. This means that these traits can be improved via selection.

Line No 6 (Mir/Kharkovkiy Etalonnyy) excelled at high adaptability by the pod and seed numbers per plant and growing season length.

Key words: breeding, genotype, Pisum sativum, productivity 